\section{Fabiano Bolpato Loures}

Alfredo Chaoubah"

Valdeci Manoel de Oliveira"'I

Alessandra Maciel Almeida ${ }^{\mathrm{IV}}$

Estela Márcia de Saraiva Campos ${ }^{\vee}$

Elenir Pereira de Paivavi

Unidade de Prática Integrada. Ortopedia e Traumatologia. Santa Casa de Juiz de Fora. Juiz de Fora, MG, Brasil

Instituto de Ciências Exatas. Universidade Federal de Juiz de Fora. Juiz de Fora, MG, Brasil

III Faculdade de Medicina. Universidade Federal de Juiz de Fora. Juiz de Fora, MG, Brasil

Vaculdade de Ciências Médicas de Minas Gerais. Universidade Federal de Minas Gerais. Belo Horizonte, MG, Brasil

Faculdade de Medicina. Universidade Federal de Juiz de Fora. Juiz de Fora, MG, Brasil

Faculdade de Enfermagem. Universidade Federal de Juiz de Fora. Juiz de Fora, MG, Brasil

\section{Correspondence:}

Fabiano Bolpato Loures

R. Severino Meireles, 23 Alto dos Passos

36025-040 Juiz de Fora, MG, Brasil

E-mail: fabiano.loures@yahoo.com.br

Received: 10/1/2013

Approved: 9/11/2014

Article avaiable from: www.scielo.br/rsp

\section{Economic analysis of surgical treatment of hip fracture in older adults}

\section{Análise econômica do tratamento cirúrgico de fratura do quadril em idosos}

\begin{abstract}
OBJECTIVE: To analyze the incremental cost-utility ratio for the surgical treatment of hip fracture in older patients.

METHODS: This was a retrospective cohort study of a systematic sample of patients who underwent surgery for hip fracture at a central hospital of a macro-region in the state of Minas Gerais, Southeastern Brazil between January 1, 2009 and December 31,2011. A decision tree creation was analyzed considering the direct medical costs. The study followed the healthcare provider's perspective and had a one-year time horizon. Effectiveness was measured by the time elapsed between trauma and surgery after dividing the patients into early and late surgery groups. The utility was obtained in a cross-sectional and indirect manner using the EuroQOL 5 Dimensions generic questionnaire transformed into cardinal numbers using the national regulations established by the Center for the Development and Regional Planning of the State of Minas Gerais. The sample included 110 patients, 27 of whom were allocated in the early surgery group and 83 in the late surgery group. The groups were stratified by age, gender, type of fracture, type of surgery, and anesthetic risk.
\end{abstract}

RESULTS: The direct medical cost presented a statistically significant increase among patients in the late surgery group $(p<0.005)$, mainly because of ward costs $(\mathrm{p}<0.001)$. In-hospital mortality was higher in the late surgery group $(7.4 \%$ versus $16.9 \%)$. The decision tree demonstrated the dominance of the early surgery strategy over the late surgery strategy: $R \$ 9,854.34$ (USD4,387.17) versus $\mathrm{R} \$ 26,754.56$ (USD11,911.03) per quality-adjusted life year. The sensitivity test with extreme values proved the robustness of the results.

CONCLUSIONS: After controlling for confounding variables, the strategy of early surgery for hip fracture in the older adults was proven to be dominant, because it presented a lower cost and better results than late surgery.

DESCRIPTORS: Aged. Hip Fractures, surgery. Orthopedic Procedures. Early Medical Intervention. Evaluation of Results of Therapeutic Interventions. 


\section{RESUMO}

OBJETIVO: Analisar a razão custo-utilidade incremental do tratamento cirúrgico da fratura do quadril de pacientes idosos.

MÉTODOS: Estudo de coorte retrospectiva, com amostra sistemática de pacientes operados por fratura do quadril em hospital polo de macrorregião de Minas Gerais, entre 2009 e 2011. Foi realizada análise da criação de árvore de decisão, considerando os custos diretos médicos. A perspectiva foi do provedor de cuidado e o horizonte temporal de um ano. A efetividade foi medida pelo tempo decorrido entre o trauma e a cirurgia, sendo criados dois grupos maiores: o da estratégia precoce e o da tardia. A utilidade foi obtida de forma transversal e indireta por meio do questionário genérico Euro QOL-5D e transformada em número cardinal utilizando-se a normativa nacional criada pelo Centro de Desenvolvimento e Planejamento Regional de Minas Gerais. A amostra contou com 110 pacientes, 27 alocados no grupo precoce e 83 no tardio. Os grupos foram controlados por idade, sexo, tipo de fratura, tipo de cirurgia e risco anestésico.

RESULTADOS: O custo direto médico mostrou-se aumentado de forma estatisticamente significativa entre os pacientes da alternativa tardia $(p<0,005)$, principalmente devido aos custos de enfermaria $(p<0,001)$. A mortalidade intrahospitalar foi maior no grupo da cirurgia tardia (7,4\% contra $16,9 \%)$. A árvore de decisão mostrou a dominância da estratégia da cirurgia precoce em relação à tardia, com $\mathrm{R} \$ 9.854,34(\mathrm{U} \$ 4,387.17)$ contra $\mathrm{R} \$ 26.754,56(\mathrm{U} \$ 11,911.03)$ por ano de vida ajustado por qualidade, respectivamente. $O$ teste de sensibilidade de extremos comprovou robustez dos resultados.

CONCLUSÕES: Após controle de variáveis confundidoras, a estratégia de cirurgia precoce para fratura do quadril em idosos mostrou-se dominante, pois apresentou menor custo e melhores resultados em relação à tardia.

DESCRITORES: Idoso. Fraturas do Quadril, cirurgia. Procedimentos Ortopédicos. Intervenção Médica Precoce. Avaliação de Resultado de Intervenções Terapêuticas.

\section{INTRODUCTION}

Hip fractures have serious repercussions in older patients. This topic is of great relevance because of high morbidity and mortality, high rate of disability in the postoperative period, and increasing costs to society with low treatment-related results. These fractures are considered one of the greatest public health problems worldwide..$^{6,7}$

The United Kingdom guidelines recommends $24 \mathrm{~h}$ as the ideal maximum time interval between trauma and surgery, ${ }^{24}$ except in cases where the patient requires adaptation of his/her clinical condition before undergoing surgery. Some authors consider the fulfillment of this ideal time interval as a criterion for assessing the quality of the service. ${ }^{23}$
Unlike developed countries, the time interval between trauma and surgery in Brazil is larger than 24h, which can worsen clinical outcomes and decrease quality of life as well as increase costs. ${ }^{4,8,14,15}$

An economic analysis of hip fracture in the older adults is required in order to better understand the current scenario of the problem and to develop appropriate coping strategies. The collective assessment of this serious clinical condition increases the decision-making capacity, because it enables the analysis of this social issue as a whole from an economic perspective, instead of individual effectiveness or efficiency criteria.

This study aimed to analyze the incremental costutility ratio for the surgical treatment of hip fracture in older patients. 


\section{METHODS}

An economic cost-utility analysis of health from the perspective of the healthcare provider was performed. The time horizon was one year. The decision-tree model of analysis was chosen because of the low complexity of the scenario and the linearity of the ailment.

Based on the Brazilian Unified Health System (SUS) classification, a retrospective cohort was created by reviewing the electronic medical records of all patients who underwent reconstructive surgery after hip fracture in the study hospital, located in Juiz de Fora, a city that is the center of a health macro-region in the state of Minas Gerais. The procedures were performed between January 1, 2009 and December 31, 2011. Inclusion criteria were age $>60$ years, compatible diagnosis [hip fracture due to low-energy trauma, osteoporosis-related (ICD-10: S72-0 and S72-1)], ${ }^{18}$ and the ability to fill in the capacity of the survey instrument. Exclusion criteria were high-energy trauma, secondary bone disease (except for osteoporosis), and nonsurgical treatment.

The variables assessed using an instrument specially developed for this purpose were gender, age, anesthetic risk score, ${ }^{1}$ type of fracture, and type of treatment.

Older patients were treated at emergency care units (the hospital's Emergency Room I) and transferred to hospitals that were equipped to treat issues of such complexity.

Dates of authorization for hospitalization (AIH; deemed date of fracture), admission at study hospital, surgery, and discharge or death were also obtained. These ranges correspond to transfer time, preoperative preparation, time until surgery, and hospitalization time.

Data on direct medical costs were collected directly at the Costs Department of the hospital and comprised ward stay, intensive care unit stay, hospital fees, additional examinations, and medical fees. Ward stay also comprised transfer time, which is included in the total hospitalization time. These costs were adjusted in accordance with the Fundação Instituto de Pesquisas Economicas (FIPE - Economic Research Institute Foundation) index ${ }^{\mathrm{a}}$ with regard to weighing health prices and were corrected until November 2012, when the field outcomes were collected. The costs and outcomes were controlled by the following independent variables: age, gender, type of fracture, type of treatment, and anesthetic risk score. Two groups were compared, early surgery, which comprised patients who underwent the procedure until the fourth day, and late surgery, comprising those who were operated on after the fourth day.

The choice of the fourth day as a cut-off point was based on the study by Fernandes et al, ${ }^{10}$ who stated that lower cut-off points would reduce the number of participants in the first group, thus hindering the comparison, and the study by Moroni et al, ${ }^{17}$ who demonstrated that values obtained after four days would impact the mortality results.

The groups were initially compared using Student's $t$-test for average age, which was a continuous variable. The Chi-square test was used for the following dichotomous variables: anesthetic risk [low (I and II) or high (III and IV)], type of fracture (femoral neck or transtrochanteric), type of treatment (substitution or synthesis), and gender (male or female).

After analysis of the medical records, telephone calls were made to determine outpatient death of nonhospitalized patients and to invite to participate in the survey, which consisted of a structured questionnaire. The EuroQOL 5 Dimensions (EQ-5D) questionnaire was used to assess the quality of life. The code transformation rules generated by the EQ-5D for the cardinal utility values were those established by the Centro para o Desenvolvimento e Planejamento Regional de Minas Gerais (CEDEPLAR - Center for the Development and Regional Planning of the State of Minas Gerais). ${ }^{\mathrm{b}}$

A deterministic susceptibility test of extreme values was performed using cost and utility confidence intervals to assess the robustness of the results. For the statistical analysis, the programs SPSS 20.0 and TreeAge Pro 2011 were used. The significance level was set at 5\%.

This study was approved by the Research Ethics Committee of the Santa Casa de Misericórdia de Juiz de Fora (Opinion 126931, on October 9, 2012).

\section{RESULTS}

Of the 110 patients, 27 were allocated into the early surgery group and 83 into the late surgery group. No statistically significant differences were observed between the groups with regard to the independent variables (Table 1).

The differences in direct medical costs of the treatment for the early and late surgery groups were statistically significant. The cost of treatment for the early surgery group was R $\$ 3,626.00$ (USD1,614.28), whereas that for the late surgery group was R $\$ 5,622.31$ (USD2,503.03)

\footnotetext{
${ }^{a}$ Fundação Instituto de Pesquisas Econômicas. IPC. Índice Mensal Acumulado. São Paulo (SP) [cited 2012 Nov 12]. Available from: http://www.fipe.org.br/web/index.asp?aspx=/web/indices/ipc/mensal_acumulado.aspx

${ }^{b}$ Andrade MV, Noronha KVM, Maia AC, Van Der Berg B, Pereira C. Estimação dos parâmetros de valorização dos estados de saúde em Minas Gerais, a partir do EQ-5D. Belo Horizonte: Cedeplar UFMG; 2013 [cited 2013 Jan 20]. Available from: http://www.geesc.cedeplar.ufmg.br/ index.php? Itemid=12\&option=com_content\&view=category\&layout=blog\&id=16
} 
Table 1. Comparison between groups. Health macro-region. Minas Gerais. Southeastern Brazil from 2009 to 2011.

\begin{tabular}{|c|c|c|c|}
\hline Variable & Early & Late & $\mathrm{p}$ \\
\hline $\mathrm{N}$ & 27 patients & 83 patients & \\
\hline Age & 78.78 years $(\mathrm{SD}=11.38)$ & 76.75 years $(S D=11.01)$ & 0.411 \\
\hline Gender (\%) & & & 0.148 \\
\hline Male & 77.8 & 62.6 & \\
\hline Female & 22.2 & 37.4 & \\
\hline Anesthetic risk (\%) & & & 0.655 \\
\hline Low & 55.5 & 50.6 & \\
\hline High & 44.5 & 49.4 & \\
\hline Fracture $(\%)$ & & & 0.105 \\
\hline Femoral neck & 44.4 & 27.7 & \\
\hline Transtrochanteric & 55.6 & 62.3 & \\
\hline Treatment $(\%)$ & & & 0.263 \\
\hline Replacement & 22.2 & 14.5 & \\
\hline Prosthesis & 77.8 & 85.5 & \\
\hline
\end{tabular}

Table 2. Direct medical costs of the early and late surgery groups. Health macro-region, Minas Gerais, Southeastern Brazil from 2009 to 2011.

\begin{tabular}{|c|c|c|c|c|}
\hline Variable & Group & $\begin{array}{c}\text { Average cost } \\
(\mathrm{R} \$)\end{array}$ & $\begin{array}{l}\mathrm{SD} \\
(\mathrm{R} \$)\end{array}$ & $\mathrm{p}$ \\
\hline \multirow[t]{2}{*}{ Ward } & Early & 794.98 & 275.10 & 0.001 \\
\hline & Late & $1,881.44$ & 968.17 & \\
\hline \multirow[t]{2}{*}{ Intensive care unit } & Early & 254.94 & 790.94 & 0.239 \\
\hline & Late & 666.69 & $1,747.31$ & \\
\hline \multirow[t]{2}{*}{ Examination } & Early & 122.78 & 160.48 & 0.511 \\
\hline & Late & 219.83 & 757.45 & \\
\hline \multirow[t]{2}{*}{ Fees } & Early & 836.83 & 629.57 & 0.231 \\
\hline & Late & 737.22 & 238.23 & \\
\hline \multirow[t]{2}{*}{ Materials } & Early & $1,297.30$ & 739.24 & 0.187 \\
\hline & Late & $1,575.82$ & $1,003.24$ & \\
\hline \multirow[t]{2}{*}{ Medical fees } & Early & 437.92 & 108.23 & 0.187 \\
\hline & Late & 536.57 & 379.58 & \\
\hline \multirow[t]{2}{*}{ Total } & Early & $3,626.00$ & $1,585.09$ & 0.004 \\
\hline & Late & $5,622.31$ & $3,441.12$ & \\
\hline
\end{tabular}

( $\mathrm{p}<0.005)$; ward costs were the item that contributed the most to this difference [R $\$ 794,98$ (USD353.92) versus $\mathrm{R} \$ 1,881.44$ (USD837.61); $\mathrm{p}<0.001$; Table 2].

The exchange rate for US dollars used in the present study was the official rate on October 1, 2013; the data analysis was completed on this day.

The average time between trauma and surgery in the early surgery group was 2.93 days $(\mathrm{SD}=1.38)$, whereas that in the late surgery group was 11.34 days $(\mathrm{SD}=7.75)(\mathrm{p}<0.001)$. The mean hospitalization of the early and late surgery groups was 7.0 days $(\mathrm{SD}=2.71)$ and 16.30 days $(\mathrm{SD}=8.26)$, respectively $(\mathrm{p}<0.001)$.

In-hospital deaths presented clinically significant differences $(7.4 \%$ in the early surgery group and $16.9 \%$ in the late surgery group). There was no statistically significant relationship between the risk of in-hospital death and time between trauma and surgery $(\mathrm{OR}=0.394$, $95 \%$ CI $0.084 ; 1.859, \mathrm{p}=0.226)$. The utility of the sample presented low average values of quality of life, albeit superior in the early surgery group $(0.592)$ than in the late surgery group $(0.523)$. 


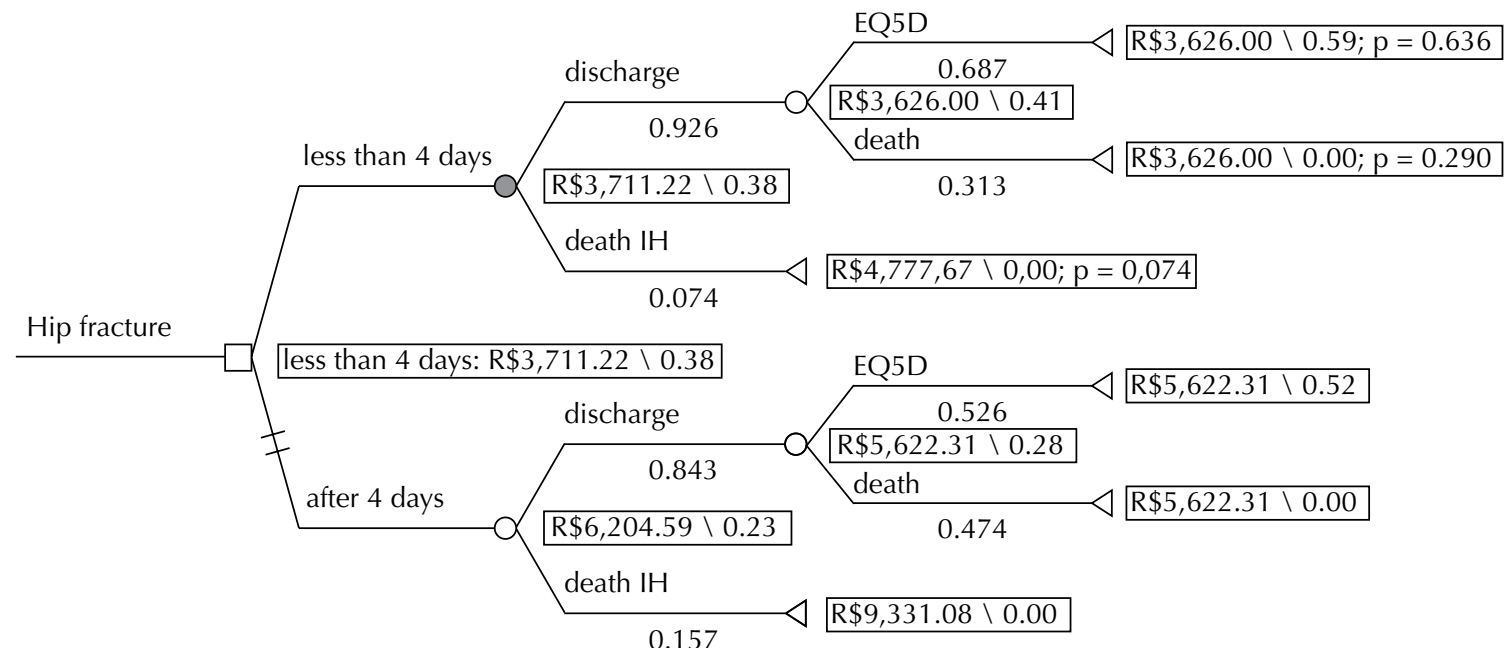

Note: values presented in $\mathrm{R} \$ /$ utility [from 0 (death) to 1 (perfect health)]

IH: in-hospital; EQ-5D: EuroQOL 5 Dimensions

Figure. Cost-utility decision tree. Health macro-region, Minas Gerais, Southeastern Brazil from 2009 to 2011.

Table 3. Cost-utility analysis of the sample. Health macro-region, Minas Gerais, Southeastern Brazil from 2009 to 2011.

\begin{tabular}{lcc}
\hline Strategy & Early & Late \\
\hline Cost & $\mathrm{R} \$ 3,711.22$ & $\mathrm{R} \$ 6,204.59$ \\
Incremental cost & & $\mathrm{R} \$ 2,493.37$ \\
Utility & 0.377 & 0.232 \\
Incremental utility & & -0.145 \\
Cost-utility & $\mathrm{R} \$ 9,854.34$ & $\mathrm{R} \$ 26,754.56$ \\
ICUR & & $\mathrm{R} \$ 17,231.20$ Dominated \\
\hline
\end{tabular}

ICUR: Incremental cost-utility ratio

A decision tree using the mean cost and utility values was created in order to establish the most appropriate strategy. The results presented in Figure 1 indicate the choice of early surgery as ideal, generating a cost of $\mathrm{R} \$ 9,854.34$ (USD4,387.17) per quality-adjusted life year (QALY) compared with the cost of R $\$ 26,754.56$ (USD11,911.03) of the late surgery strategy.

The cost, utility, and incremental cost-utility results are presented in Table 3.

The confidence intervals of the cost and utility results were estimated at $95 \%$, using the best and the worst possible scenarios for testing the stability and robustness of the model. In all simulations, the incremental cost-utility had a negative value in the early surgery strategy, thus demonstrating its lower cost and greater effectiveness. The worst-case scenario was also favorable to early surgery over late surgery [R $\$ 16,263.47$ (USD7,240.44) per QALY versus R\$41,453.69 (USD18,455.03)].

Given the stability of the results even in the worstcase scenario, the model is considered to be robust and enforceable.

\section{DISCUSSION}

This study used a sample of 110 patients, 27 of whom were allocated into the early surgery group and 83 into the late surgery group. The early surgery strategy had a lower cost and better clinical outcomes with regard to hospitalization, in-hospital deaths, and QALY.

The study sample is similar to that found in Brazilian and international literature with regard to proportionality, i.e., most individuals were females and aged around 75 years. ${ }^{7,910,19}$ The prevalence of transtrochanteric fractures has been previously observed by Rock \& Ribeiro. ${ }^{21}$ The typical treatment of transtrochanteric fractures, which in the present study were predominantly anchorages, was also observed in previous studies. $3 ., 5,20,22$

The time between the injury and surgery was longer, according to studies conducted in Brazil,, 48 and it differed from international studies, which show evidence of earlier treatment. ${ }^{12-16,19}$ The time elapse between trauma and surgery is due to the delay in preoperative patient preparation and the availability of rooms and equipment required for the surgery, 
according to a study conducted in four hospitals in the metropolitan area of New York, United States. ${ }^{19}$ This study observed a strong component associated with the delay in patient transfer.

The average direct medical cost of the surgical treatment of hip fracture in elderly patients in this study was $\mathrm{R} \$ 5,132.31$ (USD2,284.88), similar to that observed in other studies conducted in Brazil, ${ }^{4,10}$ despite the methodological differences. The present study followed the same cost measurement method adopted by Fernandes et al. ${ }^{10}$

The differences in the method of calculation and the variations in the perspective used to assess the costs related to the surgical treatment of hip fracture in the elderly in Brazil create distortions. These distortions vary from R $\$ 1,700.00$ (USD756.83) in one study that used the apportionment of SUS costs per patient ${ }^{13}$ to $\mathrm{R} \$ 24,000.00$ (USD11,729.06) in another study that assessed only the costs borne by health insur-

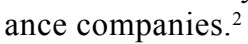

In the study by Fernandes et $\mathrm{al},{ }^{10}$ the time until surgery had a direct influence on costs, and lower expenses were associated with a shorter hospitalization time, as observed in the present study.

Costs were influenced by ward stay, unlike that reported by Araújo, Oliveira, and Bracco, ${ }^{2}$ in which the materials were responsible for higher expenses. The perspective of cost assessment may explain this difference because the present study considered the cost of implants quoted by SUS, which is cheaper.

The in-hospital deaths were different from the 5.5\% observed in the meta-analysis by Sakaki et al. ${ }^{22}$ This value may have been influenced by the results of international studies used in this meta-analysis, because it was similar to that of the early surgery group $(7.1 \%$ of in-hospital deaths).

The utility outcome measured by EQ-5D confirms the low quality of life results related to this treatment, as observed by clinical and quality-of-life outcomes. ${ }^{11}$
The limitation of comparison with other national or international results indicates the lack of this type of studies in the literature. The time between trauma and surgery has been the subject of numerous clinical studies but not of cost-effectiveness studies.

The ethical limit imposed on the present study and on others that focus on the time between trauma and surgery as the random allocation of patients is noteworthy. In such cases, observational studies provide more evidence.

A technical analysis of cost-effectiveness of both strategies in a hypothetical cohort of elderly patients with proximal femoral fracture would be much more elucidative.

The information collected from the Hospital Information System of the Information Technology Department of the Unified Health System as the source of information from January of 2008 to September of 2012 was used to select the hip fracture cases (femoral neck: synthesis, arthroplasty, and transtrochanteric) and to retrieve 215,442 authorizations for hospitalizations paid in that period. ${ }^{\circ}$

In abovementioned cohort, there is an average of 45,356 cases of proximal femoral fracture per year. If the values used in the present study were applied to this cohort, theoretically, the institution of early surgery (less than four days after the trauma) as a routine would save costs of R $\$ 90,544,636.36$ (USD40,310,139.95), save 3,882 lives, and would generate 3,129.56 extra QALY per year.

In conclusion, after controlling for the confounding variables age, gender, type of fracture, type of treatment, and anesthetic risk, the cost-utility ratio of the early surgery strategy (less than four days) was more advantageous than that of the late surgery strategy (after four days). The average time between trauma and surgery was 9.4 days, with an average hospitalization of 13.4 days. The influence of time until surgery on the results of in-hospital death was clinically significant, and its influence on total cost and hospitalization was statistically significant.

\footnotetext{
c Ministério da Saúde. DATASUS. Tecnologia de Informação a Serviço do SUS. Morbidade Hospitalar do SUS por local de internação. Notas

Técnicas. Rio de Janeiro (RJ) [cited 2012 Nov 18]. Available from: http://tabnet.datasus.gov.br/cgi/sih/midescr.htm
} 


\section{REFERENCES}

1. American Society of Anesthesiologists. New classification of physical status [editorial]. Anesthesiology. 1963;24:111.

2. Araújo DV, Oliveira JHA, Bracco OL. Custo da fratura osteoporótica do fêmur no sistema suplementar de saúde brasileiro. Arq Bras Endocrinol Metab. 2005;49(6):897-901. DOI:10.1590/S0004-27302005000600007

3. Arliani GG, Astur DC, Linhares GK, Balbachevsky D, Fernandes HJA, Reis FB. Correlação entre tempo para o tratamento cirúrgico e mortalidade em pacientes idosos com fratura da extremidade proximal do fêmur. Rev Bras Ortop. 2011;46(2):189-94. DOI:10.1590/S0102-36162011000200013

4. Bracco OL, Fortes EM, Raffaelli MP, Araújo DV, Santili C, Lazaretti-Castro M. Custo hospitalar para tratamento da fratura aguda do fêmur por osteoporose em dois hospitais-escola conveniados ao Sistema Único de Saúde. J Bras Econ Saude. 2009;1(1):3-10.

5. Chirodian N, Arch B, Parker MJ. Sliding hip screw fixation of trochanteric hip fractures: outcome of 1024 procedures. Injury. 2005;36(6):793-800. DOI:10.1016/j.injury.2005.01.017

6. Cordey J, Schneider M, Bühler M. The epidemiology of fractures of the proximal femur. Injury. 2000;31(Suppl 3):56-61. DOI:10.1016/S0020-1383(00)80033-9

7. Cummings SR, Melton LJ. Epidemiology and outcomes of osteoporotic fractures. Lancet. 2002;359(9319):1761-7. DOI:10.1016/S0140-6736(02)08657-9

8. Cunha U, Veado MAC. Fratura da extremidade proximal do fêmur em idosos: independência funcional e mortalidade em um ano. Rev Bras Ortop. 2006;41(6):195-9.

9. DeLee JC. Fractures and dislocations of the hip. In: Rockwood CA, Green D, editors. Fractures in adults. 2.ed. Philadelphia: JB Lippincott; 1984. p.1211-356.

10. Fernandes RA, Araújo DV, Takemoto MLS, Sauberman MV. Fraturas do fêmur proximal no idoso: estudo de custo da doença sob a perspectiva de um hospital público no Rio de Janeiro, Brasil. Physis. 2011;21(2):395-416. DOI:10.1590/S0103-73312011000200004

11. Guimarães FAM, Lima RR, Souza AC, Livani B, Belangero WD. Avaliação da qualidade de vida em pacientes idosos um ano após o tratamento cirúrgico de fraturas transtrocanterianas do fêmur. Rev Bras Ortop. 2011;46(Supl 1):48-54. DOI:10.1590/S0102-36162011000700012

12. Hoerer D, Volpin G, Stein H. Results of early and delayed surgical fixation of hip fractures in the elderly: a comparative retrospective study. Bull Hosp Jt Dis. 1993;53(1):29-33.
13. Krauss-Silva L. Avaliação tecnológica em saúde: densitometria óssea e terapêuticas alternativas na osteoporose pós-menopausa. Cad Saúde Pública. 2003;19(4):987-1003.

14. Lefaivre KA, Macadam SA, Davidson DJ, Gandhi $\mathrm{R}$, Chan H, Broekhuyse HM. Length of stay, mortality, morbidity and delay to surgery in hip fractures. J Bone Joint Surg Br. 2009;91(7):922-7. DOI:10.1302/0301-620X.91B7.22446

15. Majumdar SR, Beaupre LA, Johnston DW, Dick DA, Cinats JG, et al. Lack of association between mortality and timing of surgical fixation in elderly patients with hip fracture: results of a retrospective populationbased cohort study. Med Care. 2006;44(6):552-9. DOI:10.1097/01.mlr.0000215812.13720.2e

16. McGuire KJ, Bernstein J, Polsky D, Silber JH. The 2004 Marshall Urist award: delays until surgery after hip fracture increases mortality. Clin Orthop Relat Res. 2004;(428):294-301.

17. Moroni A, Hoque M, Waddell JP, Russell TA, Wippermann B, Digiovanni G. Surgical treatment and management of hip fracture patients. Arch Orthop Trauma Surg. 2014;134(2):277-81.

18. Organização Mundial da Saúde. Classificação estatística internacional de doenças e problemas relacionados à saúde - CID 10. São Paulo: EDUSP; 2003.

19. Orosz GM, Magaziner J, Hannan EL, Morrison RS, Koval K, Gilbert M, et al. Association of timing of surgery for hip fracture and patient outcomes. JAMA. 2004;291(14):1738-43. DOI:10.1001/jama.291.14.1738

20. Quevedo-Tejero EC, Zavala-Gonzáles MA, HernándezGamas AC, Hernández-Ortega HM. Fractura de cadera en adultos mayores: prevalencia e costos en dos hospitales, Tabasco, México, 2009. Rev Peru Med Exp Salud Publica. 2011;28(3):440-5.

21. Rocha FAC, Ribeiro AR. Low incidence of hip fractures in an equatorial area. Osteoporos Int. 2003;14(6):496-9. DOI:10.1007/s00198-003-1394-3

22. Sakaki MH, Oliveira AR, Coelho FF, Leme LEG, Suzuki I, Amatuzzi MM. Estudo da mortalidade na fratura do fêmur proximal em idosos. Acta Ortop Bras. 2004;12(4):242-9. DOI:10.1590/S1413-78522004000400008

23. Sund R, Liski A. Quality effects of operative delay on mortality in hip fracture treatment. Qual Saf Health Care. 2005;14(5):371-7. DOI:10.1136/qshc.2004.012831

24. Scottish Intercollegiate Guidelines Network. Management of hip fracture in older people: a national clinical guideline. Edinburgh; 2009.

Based on the master's dissertation of Loures FB, titled: "Custo-utilidade do tratamento cirúrgico da fratura do fêmur proximal em idosos, com foco no tempo entre o trauma e o tratamento," presented to the Graduate Program in Public Health of the Universidade Federal de Juiz de Fora, MG, in 2013.

The authors declare no conflict of interest. 